\title{
Analisa Penentuan Kualitas Air untuk Masyarakat Dalam Kegiatan Industri di Pabrik Sarung Tangan Namorambe
}

\author{
Yunita Pane \\ Universitas Muhammadiyah Sumatera Utara \\ yunitapane77@gmail.com

\section{Suhelmi} \\ Sekolah Tinggi Teknologi Immanuel Medan \\ suhelmi1959@gmail.com

\section{Desi Sri Pasca Sari Sembiring \\ Universitas Sains Cut Nyak Dhien Langsa \\ desisripascasari@gmail.com}

\begin{abstract}
Abstrak Penelitian ini bertujuan untuk menganalisa kegiatan Industri terhadap kualitas air sumur pada pemukiman penduduk dan untuk mengetahui pengaruh bentuk bangunan dan jarak sumur dengan lokasi sepsitank terhadap kualitas air sumur pada pemukiman penduduk di daerah Namorambe Kabupaten Deli Serdang. Penelitian ini menggunakan dianalisis secara deskriptif. Dari hasil penelitian didapat bahwa kegiatan industri berpengaruh terhadap kualitas air sumur penduduk di daerah Namorambe dimana terdapat tingkat kekeruhan (27,20 NTU) dan Besi $(0,79 \mathrm{mg} / \mathrm{L})$. Hal tersebut lebih tinggi dari baku mutu kualitas air bersih. Bentuk dan Jarak Sumur sangat berpengaruh terhadap kualitas air sumur penduduk, dimana semakin dekat lokasi industri dan septic tank terhadap sumur maka akan semakin rendah kualitas air sumur. Hasil penelitian ini dapat disarankan bila penduduk menggunakan air sumur sebagai sumber air bersih sebaiknya bangunan sumur dibeton untuk menjaga kualitas air sumur dan bila penduduk ingin membuat sumur sebaiknya jarak dengan septic tank adalah diatas 10 meter.
\end{abstract}

Kata Kunci Kualitas Air, Kualitas Sumur, Pemukiman Penduduk

\section{PENDAHULUAN}

Indonesia termasuk memiliki lahan yang luas sehingga memiliki hasil yang melimpah dari tiga abad yang lalu telah berdiri puluhan pabrik yang salah satunya adalah pabrik sarung tangan yang berada di daerah Namorambe yang padat penduduk, akan tetapi keberadaan pabrik telah membawa perubahan terhadap perkembangan kehidupan masyarakat di sekitarnnya. Setiap proses produksi akan menghasilkan produk dan limbah. Menurut Djaja (2008), limbah adalah suatu bahan yang dibuang atau terbuang dari suatu aktivitas manusia atau proses alam yang tidak mempunyai nilai ekonomi dan berdampak negatif terhadap lingkungan. Proses produksi Pabrik menghasilkan tiga macam limbah, 
yaitu : limbah padat,cair dan gas. Dan salah satu efek yang paling berperan di pabrik sarung tangan tersebut adalah limbah cairnya yang akan berdampak pada lingkungan yaitu berupa tercemarnya air.

Air merupakan suatu kebutuhan sehari - hari dan kebutuhan air semakin lama semakin meningkat sejalan dengan meningkatnya hidup manusia, baik di daerah pedesaan maupun perkotaan. Disisi lain, jumlah air relatif tidak berubah dari waktu ke waktu. Pertambahan penduduk yang cepat banyak membawa dampak negatif terhadap sumberdaya air, baik kuantitas maupun kualitasnya. Sementara itu ada sebagian penduduk kurang mendapatkan pelayanan air, tetapi di sisi lain terdapat aktivitas dan kegiatan penduduk yang meggunakan air secara berlebihan dan cenderung pemborosan air. Sumber air yang digunakan untuk memenuhi kebutuhan hidup termasuk air tanah (Rohcili,2006).

Potensi air tanah bervariasi antara tempat yang satu dengan tempat yang lain, dengan demikian pula permasalahan yang timbul juga tidak sama, namun secara umum dapat dikatakan bahwa pada setiap daerah telah terjadi penurunan cadangan air tanah serta penurunan kualitas air tanah (Sudarmadji, 2006).

Air bersih dibutuhkan dalam kebutuhan manusia untuk melakukan segala kegiatan. Sehingga perlu diketahui bagaimana air dikatakan bersih dari segi kualitas dan bisa digunakan dalam jumlah yang memadai dalam kegiatan sehari - hari manusia. Pencemaran dan penurunan kualitas air tanah berhubungan erat dengan tingkat kepadatan penduduk, sebab semakin banyak jumlah penduduk maka limbah yang dibuang ke lingkungan akan semakin besar. Selain itu kegiatan industri juga memberi andil yang cukup besar terhadap penurunan kualitas air (Trisnawulan et.al,2007).

Pencemaran terjadi di berbagai tempat, termasuk di lingkungan kita berada. Kecenderungan pencemaran terjadi mengarah pada dua hal yaitu pembuangan senyawa kimia tertentu yang makin meningkat, terutama akibat kegiatan industri dan transportasi serta akibat penggunaan bahan-bahan berbahaya oleh manusia. Kegiatan industri, transportasi, dan aktivitas manusia yang banyak mengeluarkan bahan pencemaran seringkali merusak keadaan lingkungan, salah satunya adalah air (Achmad, 2004).

Air merupakan senyawa kimia yang sangat penting bagi kehidupan manusia dan mahluk hidup lainnya dan fungsinya bagi kehidupan tidak akan dapat digantikan dengan senyawa lainnya (Achmad, 2004). Biasanya Logam kadmium (Cd) selalu dalam bentuk campuran dengan logam lain terutama dalam pertambangan timah hitam dan seng (Darmono 1995), yang terdapat di di dalam sumur daerah dekat dengan pabrik - pabrik atau perindustrian.

Ditinjau dari segi kualitas ada beberapa peryaratan yang harus dipenuhi, diantaranya kualitas fisik yang terdiri atas bau, warna dan rasa, kualitas kimia yang terdiri atas $\mathrm{pH}$, dan kualitas biologi dimana air terbebas dari mikroorganisme penyebab penyakit.Agar kelangsungan hidup manusia dapat berjalan lancar, air bersih juga harus tersedia dalam jumlah yang memadai sesuai dengan aktifitas manusia pada tempat tertentu dan kurun waktu tertentu. Pada umumnya sumber air bersih yang digunakan penduduk di Namorambe Kabupaten Deli Serdang adalah air tanah berupa sumur - sumur gali dan sumur bor yang dimanfaatkan untuk mandi,mencuci dan minum. Penggunaan air sumur gali yang meningkat dari tahun ke tahun dan dekatnya posisi sumur dengan lokasi industri dikhawatirkan akan menyebabkan penurunan kualitas air bawah tanah. Hal ini akan sangat membahayakan bagi kesehatan penduduk pengguna sumur tersebut. Melihat kenyataan tersebut mendorong peneliti untuk melihat seberapa besar kualitas air untuk 
masyarakat dalam kegaitan industri di pabrik sarung tangan namorambe kabupaten deli serdang.

\section{METODOLOGI PENELITIAN}

\subsection{Lokasi dan Waktu Penelitian}

Lokasi Penelitian dilakukan di Pabrik Sarung Tangan Kec.Namorambe Kabupaten Deli Serdang. Waktu Penelitian adalah selama 3 (tiga) bulan di mulai dari bulan Februari 2020 sampai bulan April 2020

\subsection{Analisa Data}

- Data primer adalah data yang diperoleh langsung dengan pengambilan sample air sumur yang dianalisis di laboratorium. Data mengenai pemanfaatan air oleh masyarakat diperoleh melalui isian kuisioner - kuisioner.

- Data Sekunder (data tambahan) yang diperoleh dari instansi terkait yaitu Pemerintah Kabupaten Deli Serdang, buku - buku literatur,studi pustaka, jurnal ilmiah.

\subsection{Cara Pengambilan Sampel}

Dalam penelitian ini kualitas air sumur diteliti berdasarkan 3 (tiga) faktor, yaitu :

1. Faktor kondisi sumur penduduk
a. Sumur sederhana
b. Sumur sederhana dengan beton
c. Sumur bor/pantek

2. Faktor Jarak sumur dengan lokasi industri
a. Jarak $<100$ meter
b. Jarak antara $100-200$ meter
c. Jarak antara $200-300$ meter
d. Jarak > 300 meter

3. Faktor jarak sumur dengan septitank / WC
a. Jarak $<5$ meter
b. Jarak antara $5-10$ meter
c. Jarak $>10$ meter

\subsection{Metode Analisa Data}

Jumlah di kecamatan Namorambe Kabupaten Deli Serdang berjumlah 20506 jiwa. Sampel penelitian menggunakan analisis korelasi dan regresi berganda, dengan bantuan komputer melalui program sofware SPSS (Statistical Product and Service Solution). Hubungan antara variabel (X) dengan Variabel terpengaruh yaitu pemanfaatan air bawah tanah penduduk dengan menghitung besarnya korelasi yang dinyatakan sebagai koefesien korelasi (r) dengan rumus :

$$
\mathrm{r}=\frac{b \Sigma X i Y i-\Sigma X i \Sigma Y i}{\sqrt{\left[b \Sigma X i^{2}-\{\Sigma X i\}^{2}\right]\left[b \Sigma Y i^{2}-\left\{\Sigma Y i^{2}\right\}\right]}}
$$

Adapun kriteria penilaian untuk menentukan kategori jawaban yaitu Tabel 1. 
Tabel 1. Kriteria nilai dari jawaban koesioner (Bungin,2003)

\begin{tabular}{|c|l|c|c|}
\hline No & Kriteria Penilaian & Skor & Nilai \\
\hline 1 & Ya & $13-16$ & 3 \\
\hline 2 & Tidak & $09-12$ & 2 \\
\hline 3 & Tidak Tahu & $05-08$ & 1 \\
\hline
\end{tabular}

\section{HASIL PENELITIAN}

\subsection{Komposisi Responden Berdasarkan Lama Bermukim}

Keadaan penduduk yang menjadi responden berdasarkan lama bermukim di Kecamatan Namorambe Kabupaten Deli Serdang,terdiri dari lama bermukim dari 2 tahun sampai lebih dari 11 tahun, data komposisi responden berdasarkan lama bermukim dapat dilihat pada tabel 2 .

Tabel 2. Komposisi Responden Berdasarkan Lama Bermukim

\begin{tabular}{|c|c|c|c|}
\hline No & Lama Bermukim (Tahun) & $\begin{array}{c}\text { Jumlah } \\
\text { (orang) }\end{array}$ & Persen (\%) \\
\hline 1 & $<2$ & 4 & 4.39 \\
2 & $3-5$ & 3 & 3.29 \\
3 & $6-8$ & 7 & 7.69 \\
4 & $9-11$ & 8 & 8.79 \\
5 & $>11$ & 64 & 75.84 \\
\hline \multicolumn{2}{|l|}{ Jumlah } & 91 & 100 \\
\hline
\end{tabular}

Dari Tabel 2. di dapat bahwa masyarakat dengan persentase lama bermukim adalah $>11$ tahun sebanyak 64 orang $(75,84 \%)$. Selanjutnya $9-11$ tahun sebanyak 8 orang $(8,79 \%)$, $6-8$ tahun sebanyak 7 orang $(7,69 \%),<2$ tahun sebanyak 4 orang $(4,39 \%)$, yang paling sedikit adalah $3-5$ tahun sebanyak 3 orang $(3,29 \%)$.

\subsection{Komposisi Responden Berdasarkan Pekerjaan}

Tenaga kerja atau penduduk usia kerja adalah jumlah seluruh penduduk yang secra potensial dapat memproduksi barang dan jasa. Setiap orang yang telah memasuki usia angkatan kerja akan memilih jenis pekerjaan, sesuai dengan pengetahuan, ketrampilan, kesempatan yang tersedia dan sumberdaya yang ada di sekitarnya .Tenaga kerja harus memenuhi persyaratan peraturan pemerintah, seperti batas usia tertentu. Pengertian tenaga kerja lebih luas dari pada pengertian karyawan, karena tenaga kerja orang yang bekerja didalam maupun diluar hubungan kerja. Komposisi responden berdasarkan pekerjaan dapat dilihat pada Tabel 3 .

Tabel 3. Komposisi responden berdasarkan pekerjaan 


\begin{tabular}{|c|l|c|c|}
\hline No & \multicolumn{1}{|c|}{ Pekerjaan } & $\begin{array}{c}\text { Jumlah } \\
\text { (Orang) }\end{array}$ & Persen (\%) \\
\hline 1 & PNS & 2 & $6,62 \%$ \\
2 & Pensiunan & 5 & $5,49 \%$ \\
3 & Buruh & 1 & $1,09 \%$ \\
4 & Petani & 16 & $17,58 \%$ \\
5 & Pedagang & 12 & $13,18 \%$ \\
6 & Tidak ada pekerjaan & 51 & $56,04 \%$ \\
\hline \multicolumn{2}{|l|}{ Jumlah } & 91 & 100 \\
\hline
\end{tabular}

\subsection{Komposisi Responden Berdasarkan Pendapatan}

Pengaruh Adanya pabrik - pabrik dapat dilihat dari perekonomian masyarakat yaitu tidak adanya peningkatan pendapatan yang signifikan hal ini disebabkan karena tidak adanya penduduk yang bekerja sebagai buruh pabrik tetap, adapun beberapa masyarakat yang bekerja sebagai buruh yaitu buruh lepas sehingga dapat dikategorikan memiliki pekerjaan tidak tetap. Pendapatan masyarakat di Kecamatan Namorambe dapat dilihat pada tabel 4.

Tabel 4. Pendapatan Masyarakat di Kecamatan Namorambe

\begin{tabular}{|c|l|c|c|}
\hline No & Pendapatan (Rupiah) & Jumlah (KK) & Persen (\%) \\
\hline 1 & $<500.000$ & 17 & 18,68 \\
2 & $501.000-750.000$ & 17 & 18,68 \\
3 & $751.000-999.000$ & 14 & 15,38 \\
4 & 1.000 .000 & 25 & 27,47 \\
5 & 1.499 .000 & 18 & 19,79 \\
\hline & $>1.500 .000$ & & \\
\hline \multicolumn{2}{|l|}{ Jumlah } & 91 & 100 \\
\hline
\end{tabular}

\subsection{Kualitas Air Sumur di Kecamatan Namorambe Kabupaten Deli Serdang}

Berdasarkan hasil analisis air yang dilakukan maka didapat :

Tabel 5. Hasil Analisis Air di Kecamatan Namorambe

\begin{tabular}{|c|c|c|c|c|c|c|c|c|c|c|}
\hline \multirow[t]{2}{*}{ No } & \multirow{2}{*}{$\begin{array}{c}\text { Bentuk } \\
\text { Bangunan } \\
\text { Sumur }\end{array}$} & \multirow[t]{2}{*}{ Parameter } & \multirow{2}{*}{$\begin{array}{l}\text { Baku } \\
\text { Mutu }\end{array}$} & \multicolumn{4}{|c|}{ Jarak Sumur dengan Lokasi Industri } & \multicolumn{3}{|c|}{$\begin{array}{c}\text { Jarak Sumur dengan } \\
\text { Sepsitank/WC (m) }\end{array}$} \\
\hline & & & & $<100$ & $\begin{array}{c}100- \\
200\end{array}$ & $200-300$ & $>300$ & $<5$ & $5-10$ & $>10$ \\
\hline \multirow[t]{8}{*}{1} & Sumur & $\mathrm{pH}$ & $6,5-8,5$ & 7,75 & 7,30 & 7,20 & 7,12 & 7,24 & 7,16 & 7,10 \\
\hline & Sederhana & $\mathrm{TSS}(\mathrm{mg} / \mathrm{L})$ & 40 & 80 & 60 & 60 & 40 & 80 & 70 & 65 \\
\hline & & TDS & 1000 & 640 & 5,20 & 520 & 380 & 630 & 520 & 430 \\
\hline & & Kekeruhan & 5 & 27,20 & 9,06 & 4,96 & 3,28 & 28,20 & 19,06 & 6,28 \\
\hline & & Sulfat & 250 & 14,98 & 0,90 & 0,54 & 0,38 & 11,38 & 0,89 & 0,86 \\
\hline & & $\mathrm{Ca}(\mathrm{mg} / \mathrm{L})$ & 200 & 49,20 & 46,72 & 38,93 & 36,99 & 35,21 & 29,45 & 27,89 \\
\hline & & $\mathrm{Mg}(\mathrm{mg} / \mathrm{L})$ & 150 & 16,55 & 86,35 & 8,27 & 7,09 & 16,55 & 8,27 & 8,21 \\
\hline & & Besi Total & 0,3 & 0,79 & 0,70 & 0,49 & 0,18 & 0,82 & 0,73 & 0,13 \\
\hline \multirow[t]{2}{*}{2} & Sumur & & $6,5-8,5$ & 7,60 & 7,10 & 7,10 & 7,10 & 7,60 & 7,25 & 7,15 \\
\hline & Sederhana & TSS (mg/L) & 40 & 70 & 62 & 60 & 40 & 80 & 60 & 60 \\
\hline
\end{tabular}




\begin{tabular}{|c|l|l|c|c|c|c|c|c|c|c|}
\hline \multirow{7}{*}{ Dengan } & TDS & 1000 & 610 & 540 & 520 & 380 & 640 & 520 & 520 \\
& Beton & Kekeruhan & 5 & 13,20 & 9,06 & 4,96 & 3,28 & 27,20 & 9,06 & 3,28 \\
& Sulfat & 250 & 14,98 & 0,90 & 0,64 & 0,38 & 13,42 & 0,90 & 0,85 \\
& & Ca (mg/L) & 200 & 37,20 & 36,99 & 35,93 & 34,72 & 46,70 & 39,70 & 38,93 \\
& & Mg (mg/L) & 150 & 16,55 & 9,45 & 8,27 & 7,09 & 13,13 & 9,27 & 6,23 \\
& & Besi Total & 0,3 & 0,85 & 0,70 & 0,49 & 0,14 & 0,69 & 0,56 & 0,14 \\
\hline 3 & Sumur & pH & $6,5-8,5$ & 7,40 & 7,20 & 7,11 & 7,00 & 7,60 & 7,12 & 7,00 \\
& Bor/Pendek & TSS (mg/L) & 40 & 80 & 60 & 40 & 40 & 70 & 50 & 50 \\
& TDS & 1000 & 630 & 520 & 520 & 380 & 640 & 520 & 520 \\
& Kekeruhan & 5 & 9,20 & 9,06 & 4,96 & 3,28 & 27,20 & 9,06 & 3,28 \\
& Sulfat & 250 & 3,90 & 1,98 & 0,64 & 0,38 & 14,98 & 0,90 & 0,64 \\
& Ca (mg/L) & 200 & 29,21 & 29,13 & 26,73 & 26,59 & 46,72 & 44,72 & 44,56 \\
& Mg (mg/L) & 150 & 14,55 & 8,17 & 7,09 & 6,27 & 16,55 & 8,27 & 8,27 \\
& Besi Total & 0,3 & 0,79 & 0,70 & 0,49 & 0,19 & 0,79 & 0,48 & 0,18 \\
\hline
\end{tabular}

Menurut Sutrisno (2006) ion silfat adalah salah satu ion yang banyak terjadi pada air alam. Sulfat merupakan sesuatu yang penting dalam penyediaan air untuk minum karena pengaruh sulfat pada jumlah yang banyak akan mempengaruhi kekeruhan air.

\subsection{Penurunan Kualitas Air Sumur di Kecamatan Namorambe Kabupaten Deli Serdang}

Penurunan kualitas air sumur di kecamatan Namorambe Kabupaten Deli Serdang memberikan dampak yang sangat besar terhadap masyarakat sekitar. Tanggapan responden terhadap penurunan kualitas air sumur di Kecamatan Namorambe Kabupaten Deli Serdang dapat dilihat dari tabel 6.

\section{Tabel 6. Tanggapan Responden terhadap penurunan Kualitas Air Sumur di Kecamatan Namorambe Kabupaten Deli Serdang}

\begin{tabular}{|c|c|c|c|c|c|}
\hline \multirow[b]{2}{*}{ No } & \multirow[b]{2}{*}{ Pertanyaan } & \multicolumn{4}{|c|}{ Jawaban Responden } \\
\hline & & $\begin{array}{l}\mathrm{Ya} \\
(\%)\end{array}$ & $\begin{array}{c}\text { Tidak } \\
(\%)\end{array}$ & $\begin{array}{c}\text { Tidak } \\
\text { Tahu(\%) }\end{array}$ & $\begin{array}{c}\text { Total } \\
(\%)\end{array}$ \\
\hline 1 & $\begin{array}{l}\text { Industri mengeluarkan limbah yang dapat mencemari } \\
\text { lingkungan terutama sumber air sumur } \\
\text { Kecamatan Namorambe adalah mempunyai salah satu } \\
\text { perindustrian yang dapat mengakibatkan pencemaran air }\end{array}$ & 48 & 18 & 34 & 100 \\
\hline 2 & $\begin{array}{l}\text { sumur bagi sekitarnya } \\
\text { Air yang tercemar akan menyebabkan perubahan warna air, } \\
\text { timbulnya bau yang tidak sedap dan timbulnya rasa yang }\end{array}$ & 23 & 26 & 51 & 100 \\
\hline 3 & $\begin{array}{l}\text { tidak disukai } \\
\text { Sebagian air sumur di lokasi pabrik tidak dapat digunakan } \\
\text { lagi untuk kebutuhan masyarakat sekitar karena telah }\end{array}$ & 2 & 30 & 68 & 100 \\
\hline 4 & $\begin{array}{l}\text { tercemar } \\
\text { Air sumur pada umumnya telah tercemar karena limbah } \\
\text { industri }\end{array}$ & 25 & 25 & 50 & 100 \\
\hline 5 & $\begin{array}{l}\text { Air sumur di Kecamatan Namorambe pada umumnya } \\
\text { berwarna kuning. }\end{array}$ & 46 & 32 & 22 & 100 \\
\hline 6 & $\begin{array}{l}\text { Air sumur di Kecamatan Namorambe pada umumnya } \\
\text { berminyak }\end{array}$ & 3 & 34 & 63 & 100 \\
\hline 7 & & 36 & 46 & 18 & 100 \\
\hline
\end{tabular}


Apakah ada sumur yang tidak dapat digunakan setelah terjadinya pencemaran

Tabel 5. Tanggapan responden terhadap penurunan kualitas air sumur di Kecamatan Namorambe Kabupaten Deli Serdang

\subsection{Uji Korelasi}

Hasil perhitungan statistik Analisa korelasi faktor kependudukan dengan penurunan kualitas air sumur dan pemanfataannya maka hasil uji korelasi antara variabel pengaruh (kependudukan) dengan variabel terpengaruh (penurunan kualitas air sumur dan pemanfataan air sumur), terlihat bahwa ada beberapa variabel pengaruh seperti umur,penghasilan,pekerjaan dan lama bermukim menunjukkan korelasi yang bersifat negatif. Hal ini berarti korelasi yang terjadi berlawanan arah. Adanya kenaikan nilai pada faktor kependudukan diikuti dengan penurunan pada nilai sikap masyarakat pada penurunan kualitas air sumur.

Sedangkan variabel pengaruh tingkat pendidikan menunjukkan adanya korelasi yang bersifat positif atau searah. Pada korelasi variabel pengaruh (kependudukan) terhadap variabel terpengaruh (pemanfaatan air sumur), terlihat bahwa variabel pendapatan, pendidikan, pengahasilan menunjukkan korelasi yang bernilai positif. Hal ini berarti korelasi yang terjadi bersifat searah. Sedangkan variabel umur dan lama bermukim memperlihatkan nilai korelasi negative yang berarti korelasi yang terjadi bersifat berlawanan arah.

\section{KESIMPULAN}

\subsection{Kesimpulan}

Dari hasil penelitian yang telah dilakukan dapat diambil kesimpulan sebagai berikut :

Kegiatan industri berpengaruh terhadap kualitas air sumur penduduk di Kecanatan Namorambe Kabupaten Deli Serdang dimana : Pada sumur sederhana nilai TSS (80 $\mathrm{mg} / \mathrm{L})$, tingkat kekeruhan $(27,20 \mathrm{NTU})$ dan besi total $(0,9 \mathrm{mg} / \mathrm{L})$, Pada sumur sederhana dengan beton nilai TSS (70 mg/L), tingkat kekeruhan $(13,20 \mathrm{NTU})$ dan besi total $(0,79$ $\mathrm{mg} / \mathrm{L})$, Pada sumur bor/pantek nilai TSS (80 mg/I), tingkat kekeruhan $(9,200 \mathrm{NTU})$ dan besi total $(0,79 \mathrm{mg} / \mathrm{L})$.

Bentuk bangunan sumur berpengaruh terhadap kualitas air sumur penduduk, semakin sederhana bentuk bangunan sumur maka akan semakin rendah kualitas air sumur, begitu juga dengan jarak lokasi industri dan septictank/WC terhadap bangunan sumur berpengaruh terhadap kualitas air sumur, dimana semakin dekat lokasi industri dan septic tank terhadap bangunan sumur maka akan semakin rendah kualitas air sumur.

\subsection{Saran}

Dari hasil penelitian yang telah dilakukan dapat disarankan hal - hal sebagai berikut:

1.Bila penduduk menggunakan air sumur sebagai sumber air bersih sebaiknya bangunan sumur di beton untuk menjaga kualitas air sumur.

2. Bila penduduk ingin membuat sumur sebaiknya jarak sumur dengan septic tank adalah diatas 10 meter.

\section{DAFTAR PUSTAKA}


Achmad,2004, Kimia Lingkungan, Andi, Jogyakarta.

Bungin, B.2003, Analisis Data Penelitian Kualitatif Pemahaman Filosofis dan Metodologis ke Arah Pengawasan Model Aplikasi.PT.Rajagrafindo Persada.Jakarta

Darmono,2001, Lingkungan Hidup dan Pencemaran, Universitas Indonesia Press, Jakarta.

Departemen Kesehatan RI,1991, Pedoman Kualitas Air, Departemen Kesehatan RI, Jakarta.

Djaja, W. 2008. Langkah Jitu Membuat Kompos dari Kotoran Ternak dan Sampah. Jakarta: Agro Media Pustaka.

Peraturan Menteri Kesehatan RI.No.416/Menkes/IX/1990,Tentang Syarat - syarat Pengurusan Kualitas Air.

Rochili,F.2006.Limbah Domestik.Penerepan Air dan Eksploitasi Air Tanah,Tekno Limbah, Vol.1 tahun 2006.Hal.13-15, ISSN; 1412-5009.Pusat Pengambangan Teknologi Limbah Cair,Yogyakarta.

Sudarmadji 2006. Perubahan Kualitas Airtanah Di Sekitar Sumber Pencemar Akibat Bencana Gempa Bumi. Forum Geografi, 20(2):99-11.

Sutrisno,2006.Teknologi Penyediaan Air Bersih,Rineka Cipta,Jakarta.

Trisnawulan,A.M.,Wayan,B.S dan Ketut,S.,2007. Analisis Kualitas Air Sumur Gali di Kawasan Pariwisata Sanur.Denpasar:Ecotropic Journal,Volume 2. 